\title{
Trace metals in phosphate fertilizers used in Eastern Mediterranean countries
}

Valérie Azzi ${ }^{1,2,3}$, Antoine G. El Samrani ${ }^{1}$, Bruno Lartiges ${ }^{2}$, Ahmad Kobeissi ${ }^{4}$, Ali Kanso ${ }^{1}$, Véronique Kazpard ${ }^{1}$

${ }^{1}$ Platform for Research and Analysis in Environmental Sciences, Doctoral School of Science and Technology, Faculty of Sciences, Lebanese University, P.O Box. 5, Campus Rafic Hariri-BeirutLebanon. valerie.azzi@hotmail.com, antoineelsamrani@ul.edu.lb, alikanso@live.com, kveronique@ul.edu.lb

${ }^{2}$ University of Toulouse (Paul Sabatier), Geosciences Environment Toulouse (UMR CNRS-UPS 5563 IRD 234), 14 Av. E. Belin, 31400 Toulouse, France. bruno.lartiges@ get.omp.eu

${ }^{3}$ Lebanese Agriculture Research Institute (LARI), Fanar, Lebanon.

${ }^{4}$ Faculty of Sciences, Lebanese University, P.O Box. 5, Campus Rafic Hariri-Beirut- Lebanon. ahkobeissi@ul.edu.lb

Keywords: P-Fertilizers, phosphate, sulfate, trace metal, XRD

Correspondence: V. Azzi, Platform for Research and Analysis in Environmental Sciences, Doctoral School of Science and Technology, Faculty of Sciences, Lebanese University, P.O Box. 5, Campus Rafic Hariri-Beirut- Lebanon.

E-mail: valerie.azzi@hotmail.com 


\begin{abstract}
Phosphate fertilizers represent major sources of trace metal contaminants in agricultural soils. To predict the inputs and the fate of trace metals in soils of the eastern Mediterranean region, a speciation study was conducted using a total of 44 phosphate fertilizers commercialized in the area. The contents in major anions and potentially toxic metals $(\mathrm{Zn}, \mathrm{Pb}, \mathrm{Cd}$, and $\mathrm{Cu})$ were determined using Atomic Absorption Spectrometry (AAS) and X-Ray Fluorescence Spectrometry (XRF). The nature of mineral phases in the fertilizer was characterized using X-ray diffraction and Fourier Transform Infrared Spectrometry. The results show that sulfates are the main Cd-bearing phases when present in the $\mathrm{P}$-fertilizer. The contents in $\mathrm{Zn}$ and $\mathrm{Pb}$ were linearly related, whereas the levels of $\mathrm{Sb}, \mathrm{Ag}, \mathrm{Pd}, \mathrm{Nb}, \mathrm{Mo}$ and $\mathrm{P}_{2} \mathrm{O}_{5}$ were strongly correlated to each other. The annual average inputs of $\mathrm{Zn}, \mathrm{Cu}, \mathrm{Pb}$ and $\mathrm{Cd}$ were calculated to be 922, 124, 26 and $6 \mathrm{~g} / \mathrm{ha} / \mathrm{year}$, respectively. Even though such inputs comply with the maximal metals concentrations authorized in temperate countries, an accumulation of those metals in the typical arid and alkaline soils of the eastern Mediterranean countries is expected.
\end{abstract}




\section{Introduction}

Phosphate fertilizers are chemical compounds produced from the acid treatment of apatite minerals $\left(\mathrm{Ca}_{5}\left(\mathrm{PO}_{4}\right)_{3}[\mathrm{~F}, \mathrm{OH}\right.$ or $\left.\mathrm{Cl}]\right)$ that naturally contains minor amounts of trace metals [1]. The level of potentially toxic metals in the phosphate fertilizer depends both on the origin of the phosphate ore and on the fertilizer production process [2-4]. Thus, sedimentary phosphate rocks (about 75 to $80 \%$ of phosphate resources) contain 50 to $200 \mathrm{mg} / \mathrm{kg}$ of uranium and 2 to $20 \mathrm{mg} / \mathrm{kg}$ of thorium, whereas phosphate ores of igneous or metamorphic origins (15-17\% of P-resources) show a maximum of $10 \mathrm{mg} / \mathrm{kg}$ in uranium but are rich in thorium and rare earth elements [3, 5]. The remaining 2 to $3 \%$ of phosphate ores originate from biogenic sources such as bird and bat guano deposits and mainly contain nitrogen and phosphorus [6, 7]. Radiological surveys of workers handling fertilizers confirm their exposition to high levels of radioactive elements $[2,8]$.

More than 30 million tons of phosphate fertilizers are used annually in the world to increase crop production and to ensure successful harvests [9-11]. This represents significant sources of potentially toxic metals in agricultural soils $[12,13]$. Thus, arsenic, cadmium, zinc, iron and lead as trace metals, Uranium-238 $\left({ }^{238} \mathrm{U}\right)$, Thorium-232 $\left({ }^{232} \mathrm{Th}\right)$, Potassium-40 $\left({ }^{40} \mathrm{~K}\right)$ and Radium-226 $\left({ }^{226} \mathrm{Ra}\right)$ [2, 12, 14-17] as radionuclides, have been shown to accumulate in cultivated soils following phosphate fertilization $[4,18-21]$.

Much less investigated is the influence of fertilizer type on the fate of potentially toxic metals in the soil. Thawornchaisit and Polprasert [22] showed that the nature of phosphate phase in triple superphosphate, diammonium phosphate and phosphate rock, contributes to stabilize cadmium in contaminated soils. Similarly, Zhang and $\mathrm{Pu}$ [23] evidenced a change in the availability of cadmium, copper, lead and zinc, following applications of rock phosphate, calcium magnesium phosphate, limestone and palygorskite. In the context of the remediation of contaminated soils, 
many authors have also demonstrated that the stabilization of potentially toxic metals such as $\mathrm{Pb}$, $\mathrm{Cu}$, or $\mathrm{Zn}$, depends on the nature of phosphate rock used [24-26].

Toxic metals can be harmful to ecosystems and to humans due to their persistence in soil and their potential to enter the human food chain after accumulation in vegetables and consumables $[13,27]$. Concentrations of $\mathrm{Cd}, \mathrm{Cr}, \mathrm{Pb}$ and $\mathrm{Hg}$ in fertilizers are regulated in most of the eastern Mediterranean countries but the Maximal Admissible Concentrations (MAC) differ from one country to another. Thus, cadmium and lead MAC in Lebanon are higher than those set in Finland and Germany [28, 29]. Actually, in the Middle East, contrary to European countries, soils are alkaline and submitted to arid and sub-arid climates, thus enhancing the potential for trace metals accumulation. Therefore, Maximal Admissible Concentrations of potentially toxic metals and trace elements in fertilizers used in eastern Mediterranean countries should be adapted to the local context.

A predictive approach of the fate in soils of trace metals originating from phosphate fertilizers is therefore of great interest. It should not only be based on the determination of the total metal content in the soil, but also on the nature of the metal bearing phases since phosphate fertilizers are made up of at least two major phases. In this paper, the aim is to incite emerging eastern Mediterranean countries to set new limits of trace metals in phosphate fertilizers and better control their use in alkaline soils. Thus, we investigate the various potentially toxic metals-bearing phases present in phosphate fertilizers commercialized in the eastern Mediterranean region. Correlations between trace elements, metals, phosphate and sulfate contents in the fertilizers provide a clearer picture of metal contaminant fate in the treated soil. 


\section{Experimental}

\subsection{Fertilizer materials}

A list of most commercialized phosphate fertilizers in the eastern Mediterranean region (Lebanon, Egypt, Iraq, Syria, Kingdom of Saudi Arabia, Kurdistan and Turkey) was obtained from the Lebanese Agricultural Research Institute. A total of 44 samples were then purchased (Table 1). The P-fertilizer samples selected include two liquid P-fertilizers and 42 solid P-fertilizers. Based on the data sheets provided with each sample material, the 44 P-fertilizers were partitioned into Potassium Phosphate (2 samples), Urea Phosphate (2 samples), Superphosphate (2 samples), and Nitrogen-Phosphorous and Potassium (NPK) (38 samples). The samples were crushed and homogenized in an agate mortar, and then transferred into hermetically sealed polyethylene containers to be preserved from humidity and moisture.

\subsection{Gross characterization of fertilizer samples}

Solutions $(1 \mathrm{~g} / \mathrm{L})$ of each P-fertilizer were prepared with distilled water. $\mathrm{pH}$ (Adwa AD 1000 $\mathrm{pH} / \mathrm{mV} \&$ Temp. meter) and conductivity (WTW Cond 330i) were then measured. The solutions were filtered through a $0.45 \mu \mathrm{m}$ Nylon filter in order to analyze the major dissolved anions $\left(\mathrm{PO}_{4}{ }^{3-}\right.$,

$\mathrm{Cl}^{-}, \mathrm{SO}_{4}{ }^{2-}$ and $\mathrm{NO}_{3}{ }^{-}$) by ion chromatography (Shimadzu Shim-pack IC-A3). Concentrations of $\mathrm{K}^{+}$ and $\mathrm{Na}^{+}$were determined using a Biotech engineering Management Co. Ltd flame photometer (AFP 100). The residue on the filter was dried at room temperature and analyzed by X-ray diffraction.

\subsection{Nature of heavy metal bearing phases}

X-ray diffraction analyses were carried out using a D8 Bruker diffractometer. The collected diffractograms were analyzed using the EVA software coupled to powder diffraction files provided 
by the interactive center for diffraction data ICDD. The various chemical groups in P-fertilizers were identified using Fourier Transform Infrared Spectrometry (FTIR, 6300 JASCO) in transmission mode. Pellets were prepared by mixing a $1 \%(\mathrm{w} / \mathrm{w})$ of the P-fertilizer with $\mathrm{KBr}$. The spectra were recorded in the $4000-400 \mathrm{~cm}^{-1}$ range at $4 \mathrm{~cm}^{-1}$ resolution.

\subsection{Quantitative assessment of heavy metal contaminants}

A pre-calibrated Thermo Scientific Niton XL2 X-Ray tube-based X-Ray fluorescence (XRF) analyzer was used in the bulk mode to measure the levels of $\mathrm{Sb}, \mathrm{Pd}, \mathrm{Ag}, \mathrm{Mo}, \mathrm{Nb}, \mathrm{Zr}, \mathrm{Bi}$, and $\mathrm{Mn}$. $\mathrm{Cd}, \mathrm{Zn}, \mathrm{Pb}, \mathrm{Fe}, \mathrm{Cu}$ and $\mathrm{Ca}$ were determined by atomic absorption spectrometry (AAS) using a Rayleigh WXF-210 AA Spectrophotometer and WF-10A Autosampler. A 3 g amount of Pfertilizer was dissolved in aqua regia formed by freshly mixing $21 \mathrm{~mL}$ of hydrochloric acid $(\mathrm{HCl}$, 12 mol. $\left.\mathrm{L}^{-1}\right)$ with $7 \mathrm{~mL}$ of nitric acid $\left(\mathrm{HNO}_{3}, 14\right.$ mol.L $\left.\mathrm{L}^{-1}\right)$ (ISO 11466:1995). After 16 hours at room temperature, the mixture was digested at $120^{\circ} \mathrm{C}$ for 2 hours. After cooling, $10 \mathrm{~mL}$ of diluted nitric

acid $\left(\mathrm{HNO}_{3}, 0.5 \mathrm{~mol} . \mathrm{L}^{-1}\right)$ were added, and the digested samples were filtered through a $0.45 \mu \mathrm{m}$ PTFE filter (Millipore). The filtrate was diluted to $50 \mathrm{~mL}$ with nitric acid $0.5 \mathrm{~mol} \cdot \mathrm{L}^{-1}$ and stored at $4^{\circ} \mathrm{C}$ before analysis. The instrument was calibrated using manually prepared standard solutions of each metal. Blanks for AAS analysis were prepared from $\mathrm{HCl}$ and $\mathrm{HNO}_{3}(3: 1)$ solution by using the same digestion protocol as with P-Fertilizer. Digestions were carried out per batch of 12, which includes 3 replicates of each sample and 3 blanks.

\subsection{Statistical analysis}

All the data reported represent an average of three replicates with standard deviation. XL-STAT software (Version 2009.3.02) was used to treat the data. The observations and correlations between all parameters were tested using Principal Component Analysis (PCA), Pearson (n) type. 


\section{Results and discussion}

\subsection{Mineral phases and functional groups}

Archerite or biphosphammite $\left(\left(\mathrm{NH}_{4}, \mathrm{~K}\right) \mathrm{H}_{2} \mathrm{PO}_{4}\right)$ was the dominant crystallized phase in potassium phosphate fertilizers, whereas urea phosphatic acid $\left(\mathrm{CO}\left(\mathrm{NH}_{2}\right)_{2}\left(\mathrm{H}_{3} \mathrm{PO}_{4}\right)\right)$ was typical of the urea phosphate group. Anhydrite $\left(\mathrm{CaSO}_{4}\right)$, chlorapatite $\left(\mathrm{Ca}_{10}\left(\mathrm{PO}_{4}\right)_{6} \mathrm{Cl}_{2}\right)$, and minor amounts of Cadmium Lead Phosphate Hydroxide $\left(\left(\mathrm{CdPb}_{9}\right)\left(\mathrm{PO}_{4}\right)_{6}(\mathrm{OH})_{2}\right)$ were found in the superphosphate group. In the case of NPK fertilizers, biphosphammite, syngenite $\left(\mathrm{K}_{2} \mathrm{Ca}\left(\mathrm{SO}_{4}\right)_{2} \cdot \mathrm{H}_{2} \mathrm{O}\right)$, carnalite $\left(\mathrm{KClMgCl}_{2} \cdot 6 \mathrm{H}_{2} \mathrm{O}\right)$, fluorapatite $\left(\mathrm{Ca}_{10}\left(\mathrm{PO}_{4}\right)_{6} \mathrm{~F}_{2}\right)$, niter mineral $\left(\mathrm{KNO}_{3}\right)$ were distinguished with traces of urea $\left(\mathrm{CO}\left(\mathrm{NH}_{2}\right)_{2}\right)$ (Typical DRX diffractograms are shown in Supporting Information). Glauconite $\left((\mathrm{K}, \mathrm{Na})\left(\mathrm{Fe}^{3+}, \mathrm{Al}, \mathrm{Mg}_{2}\right)(\mathrm{Si}, \mathrm{Al})_{4} \mathrm{O}_{10}(\mathrm{OH})_{2}\right)$ was identified in one sample of P-fertilizers. Likewise, montmorillonite was recognized in three NPK fertilizers. Such clay minerals are usually found disseminated in calcareous rocks, and may occur as impurities in the stockpiles of raw materials.

If fluorapatite $\left(\mathrm{Ca}_{10}\left(\mathrm{PO}_{4}\right)_{6} \mathrm{~F}_{2}\right)$ is a likely residue of the initial phosphate ore $[4,30]$, the other mineral phases are classically formed during processing. Thus, the assemblage archerite, biphosphammite, syngenite, halite, and calcite, has previously been reported in the literature in Pfertilizers [31]. Syngenite in NPK fertilizers is often found inter-grown and enclosed within the biphosphamite phase [32], which itself results from the loss of one ammonia from phosphammite $\left(\mathrm{NH}_{4}\right)_{2} \mathrm{HPO}_{4}$. Gypsum obtained as by-product during the preparation of phosphoric acid upon addition of sulfuric acid to the phosphate rocks, is transformed to anhydrite and calcium hydrogen phosphate hydrate $\left(\mathrm{Ca}\left(\mathrm{H}_{2} \mathrm{PO}_{4}\right)_{2} \cdot \mathrm{H}_{2} \mathrm{O}\right)$ in the superphosphate under high temperature [33]. These components were previously reported by Makweba and Holm [8] as the main phosphate 
compounds present in superphosphate fertilizer. Calcium carbonate has also been reported to occur in rock phosphate [34].

Infrared spectra reveal a predominant band around $1100 \mathrm{~cm}^{-1}$ in superphosphate but less intense in urea phosphate, NPK and potassium phosphate, attributed to the P-O symmetric stretching vibrations in the $\mathrm{PO}_{4}$ group [34-35] (See figure $\mathrm{S} 2$ in Supporting Information). The absorbance bands at $680-610 \mathrm{~cm}^{-1}$ in superphosphate and NPK samples, and $840-810 \mathrm{~cm}^{-1}$ in urea phosphate, NPK and potassium phosphate samples, confirm the presence of sulfate and nitrate groups (S-O and $\mathrm{N}-\mathrm{O}$ vibrations, respectively) $[35,36]$. The $\mathrm{N}-\mathrm{H}$ bond in ammonium ion is characterized by a strong peak at $1390 \mathrm{~cm}^{-1}[36,37]$. The band at $1650-1590 \mathrm{~cm}^{-1}$ in urea phosphate, potassium phosphate and NPK, is also attributed to the presence of N-H bond. The broad absorption band around $3000-2850 \mathrm{~cm}^{-1}$ suggests the presence of $\mathrm{C}-\mathrm{H}$ bond in potassium phosphate and urea phosphate fertilizers [38]. Hydroxyl groups and adsorbed water are identified in the $3670-3200 \mathrm{~cm}^{-}$ ${ }^{1}$ region in all the samples $[34,39]$. Such hydration is also observed in the NPK samples at the wavelength number of $3169 \mathrm{~cm}^{-1}$ [34]. N-H, S-O and N-O bonds were identified in $85 \%, 77 \%$ and $70 \%$ of P-fertilizers, respectively.

In the FTIR transmission mode, the absorbance intensity is directly proportional to the abundance of a given chemical bond. Hence, the intensity ratios of the typical bands characterizing the P-fertilizers may provide valuable insights into the relative abundance of the chemical groups considered. Fig. 1 presents the cumulative frequency for P-fertilizers as a function of the band intensity ratios $\mathrm{I}_{\mathrm{P}-\mathrm{O}} / \mathrm{I}_{\mathrm{N}-\mathrm{O}}, \mathrm{I}_{\mathrm{P}-\mathrm{O}} / \mathrm{I}_{\mathrm{S}-\mathrm{O}}$ and $\mathrm{I}_{\mathrm{P}-\mathrm{O}} / \mathrm{I}_{\mathrm{N}-\mathrm{H}}$. About $73 \%$ of the samples yielded $\mathrm{I}_{\mathrm{P}-\mathrm{O}} / \mathrm{I}_{\mathrm{N}-\mathrm{H}}$ ratios $<1$, which means that the P-O bond is then less abundant than the $\mathrm{N}-\mathrm{H}$ bond. In $77 \%$ and $70 \%$ of the samples, $\mathrm{P}-\mathrm{O}$ bonds were more frequent than $\mathrm{S}-\mathrm{O}$ and $\mathrm{N}-\mathrm{O}$ bonds, respectively $\left(\mathrm{I}_{\mathrm{P}-\mathrm{O}} / \mathrm{I}_{\mathrm{N}-\mathrm{O}}\right.$ and $\mathrm{I}_{\mathrm{P}-}$ 
$\mathrm{o} / \mathrm{I}_{\mathrm{S}-\mathrm{O}}$ greater than 1 ). This implies that phosphate is more abundant than nitrate and sulfate, and that nitrogen is mainly present as ammonium and not as nitrate in P-fertilizers.

\subsection{Geochemical characteristics of fertilizers}

The main chemical characteristics and amounts of major components and of trace metals within the P-fertilizers investigated are listed in Table 1. The $\mathrm{pH}$ of P-fertilizer solutions ranged from 2.2 to 8 whereas the conductivity was measured between 0.41 and $5.55 \mathrm{mS} / \mathrm{cm}$. However, the $\mathrm{pH}$ measured for a solution of a given fertilizer group displayed no significant variation. Urea phosphate yields the lowest $\mathrm{pH}$ values $(2.27 \pm 0.05)$ among the fertilizer solutions but not the greatest conductivity $(1.78 \pm 0.19 \mathrm{mS} / \mathrm{cm})$. Potassium phosphate and urea phosphate lead to the highest conductivity because of their solubility in water. Such solubility can be related to the origin of the phosphate ore and to the type of fertilizer process. It is worth noting that the electrical conductivity of P-fertilizer solutions varies within a wide range for each fertilizer group. This suggests that the solubilization mechanism of fertilizers within a given group may drastically change, which is of great interest to properly understand the migration of trace metals in soils when released from fertilizers.

The level of $\mathrm{P}_{2} \mathrm{O}_{5}$ ranged from 2.82 to $53 \%$, that of $\mathrm{SO}_{3}$ between 0 and $34 \%, \mathrm{Cl}$ between 0 and $0.02 \%, \mathrm{~K}_{2} \mathrm{O}$ between 0 and $45 \%$ and $\mathrm{Na}$ between 0.15 and $3.8 \%$. The highest concentrations in $\mathrm{P}_{2} \mathrm{O}_{5}$ were found in superphosphate, potassium phosphate and urea phosphate, whereas the lowest P-level was found in NPK.

Among toxic metals, cadmium has received a considerable attention and several studies focused on Cd availability since it can be easily absorbed by plants. Cadmium concentrations ranged from 0.62 to $9.43 \mathrm{mg} / \mathrm{kg}$ with a mean value of $3.16 \mathrm{mg} / \mathrm{kg}$, superphosphate showing the highest concentration in cadmium, i.e. $9.43 \mathrm{mg} \mathrm{Cd} / \mathrm{kg}$ (Table 1). Such values lie within the range reported 
for Cd in phosphate rocks $(0.1-60 \mathrm{mg} / \mathrm{kg})[6,40]$ and in phosphate fertilizers $(0.1-170 \mathrm{mg} / \mathrm{kg})[2$, 27, 41]. If the $\mathrm{Cd}$ level is normalized to the $\mathrm{P}$ concentration in the fertilizer, the average $\mathrm{Cd}$ concentration in our fertilizers is $76.53 \mathrm{mg} / \mathrm{kg}-\mathrm{P}$. The $\mathrm{Cd}$ concentrations in Potassium Phosphate and Urea phosphate were below $22 \mathrm{mg} \mathrm{Cd} / \mathrm{kg}$-P, whereas Cd in superphosphate $(58.71 \pm 19.3 \mathrm{mg}$ $\mathrm{Cd} / \mathrm{kg}-\mathrm{P}$ ) was much higher in comparison with literature data [42]. All samples exceeded the $\mathrm{Cd}$ concentration limit set by the German Fertilizer Ordinance (21.2 mg Cd/kg-P) [10, 13] (Fig. 2). According to the literature, Cd should be essentially associated with tricalcium phosphate [43]. In the present study, however, a fairly good correlation was found between $\mathrm{Cd}$ and $\mathrm{SO}_{4}{ }^{2-}$ in superphosphate, NPK-fertilizers, urea phosphate and potassium phosphate. The substitution of $\mathrm{Ca}$ with $\mathrm{Cd}$ results from a $\mathrm{Cd}^{2+}$ ionic radius $(0.109 \mathrm{~nm})$ similar to that of $\mathrm{Ca}^{2+}(0.114 \mathrm{~nm})$, thus leading to a Cd-P or Cd-S bond and the formation of $\mathrm{Cd}_{3}\left(\mathrm{PO}_{4}\right)_{2}$ and/or $\mathrm{CdSO}_{4}$ within the fertilizers [44]. The relationship between $\mathrm{Cd}$ and sulfate is conditioned to the presence of high sulfate contents in the NPK group of higher $\mathrm{pH}$ (Table 1). Such result is reminiscent of Cd speciation studies in the roots of barley and lettuce [44], showing that most of cadmium ions were bound to ligands containing $\mathrm{SO}_{4}$.

Lead was present in all fertilizer samples. The highest concentrations were measured in potassium phosphate and NPK samples with $16 \pm 11$ and $14 \pm 9 \mathrm{mg} \mathrm{Pb} / \mathrm{kg}$, respectively. All the samples were below the limit of $150 \mathrm{mg} \mathrm{Pb} / \mathrm{kg}$ (Fig. 3a) [13]. During the manufacturing process of P-fertilizer from phosphate rocks, the precipitation of phosphogypsum after sulfuric acid addition may capture $\mathrm{Pb}$ as insoluble lead sulfate (anglesite $\mathrm{PbSO}_{4}$ ) [40]. Indeed, lead sulfate is barely soluble whereas lead phosphate solubility in water is found to increase with a decrease in $\mathrm{pH}$ to 4 [45]. Hence, during the manufacturing of phosphate fertilizer, if sulfate is present, it will compete with phosphate to precipitate lead. In contaminated soils, previous studies have shown that $\mathrm{Pb}$ can 
be stabilized by the addition of hydroxyapatite to form pyromorphite-like minerals $\left(\mathrm{Pb}_{10}\left(\mathrm{PO}_{4}\right)_{6} \mathrm{X}_{2}\right)$ where $\mathrm{X}$ can be replaced with $\mathrm{OH}, \mathrm{Cl}$ or $\mathrm{F}$. Hydroxyapatite may also fix $\mathrm{Cd}$ and $\mathrm{Zn}$ to lead to the formation of cadmium lead phosphate hydroxide $\left(\mathrm{CdPb}_{9}\left(\mathrm{PO}_{4}\right)_{6}(\mathrm{OH})_{2}\right)$, or fluorapatite $[25,26]$. Such mineral phases in the fertilizers are geochemically stable with reduced solubility allowing lead to accumulate in soil without being significantly absorbed by plants $[24,25,40]$.

Essential trace elements for plants such as $\mathrm{Zn}, \mathrm{Cu}, \mathrm{Fe}, \mathrm{Mo}, \mathrm{Mn}$ and $\mathrm{B}$ are added to data sheets of the fertilizers as TE (Trace elements). Actually, most of the samples collected were not labelled as containing $\mathrm{Zn}, \mathrm{Cu}, \mathrm{Fe}$ and $\mathrm{Ca}$ (Table 1).

The zinc concentrations in the P-fertilizers ranged from $29 \mathrm{mg} / \mathrm{kg}$ to $5735 \mathrm{mg} / \mathrm{kg}$ with a mean value of $496 \mathrm{mg} / \mathrm{kg}$. Expressed on P-basis, the overall mean in P-fertilizers was $8574 \mathrm{mg} \mathrm{Zn/kg-P}$. Zinc showed elevated values in NPK-fertilizers with a mean value of $541 \mathrm{mg} / \mathrm{kg}$. The average zinc levels in urea phosphate, superphosphate and potassium phosphate were $141 \pm 1,239 \pm 207$ and $250 \pm 63 \mathrm{mg} \mathrm{Zn} / \mathrm{kg}$, respectively. Such range is consistent with previous reports for phosphate rock (17.7-299.3 mg Zn/kg) [40] and for phosphate fertilizers (50-1500 mg Zn/kg) (Fig. 3b) [11]. Only 2 NPK-fertilizers had Zn concentrations above the limit value of $5000 \mathrm{mg} / \mathrm{kg}$ [13]. Since both zinc and cadmium belong to the same group in the periodic system of elements and have a similar nuclear structure and ionic radius, they may compete in the soil for similar binding sites $[11,46]$. On the other hand, some authors have demonstrated an antagonistic interaction for $\mathrm{Cd}$ and $\mathrm{Zn}$ uptake and translocation in plants, an increase in $\mathrm{Zn}$ uptake mitigating $\mathrm{Cd}$ accumulation in crops [47].

Copper, like Zn, showed elevated values in NPK-fertilizers and potassium phosphate samples with a mean value of $74.86 \pm 118$ and $30.63 \pm 40.3 \mathrm{mg} \mathrm{Cu} / \mathrm{kg}$ respectively. The average value for $\mathrm{Cu}$, i.e. $66.6 \pm 111 \mathrm{mg} \mathrm{Cu} / \mathrm{kg}$, is lower than the worldwide range for rock phosphate $(5.5-130 \mathrm{mg} / \mathrm{kg})$; 
only 4 NPK-fertilizer samples gave a higher concentration. $90 \%$ of the samples had a concentration below $100 \mathrm{mg} \mathrm{Cu} / \mathrm{kg}$ (Fig. 3c), the value set by AFNOR (Association Française de Normalisation) for fertilizers, but only $8 \%$ were above the minimum concentration for $\mathrm{Cu}$ in Germany $(200 \mathrm{mg} / \mathrm{kg}$ ) and all the samples remained below the limit of $900 \mathrm{mg} / \mathrm{kg}$ set for agricultural fertilizers in the same country [13].

Iron and calcium were present in abundance in NPK-fertilizers and superphosphate where they reached 1.7 and $1.4 \mathrm{~g} \mathrm{Fe} / \mathrm{kg}$ and 9.2 and $149.3 \mathrm{~g} \mathrm{Ca} / \mathrm{kg}$ respectively for the two kinds of phosphate fertilizers mentioned above. $65 \%$ of the tested products displayed Fe concentrations above $500 \mathrm{mg}$ $\mathrm{Fe} / \mathrm{kg}$ and all the samples except one NPK-fertilizer had the Fe concentrations below the minimum of $10 \mathrm{~g} \mathrm{Fe} / \mathrm{kg}$ defined by the German Fertilizer Ordinance for agricultural products [13].

The standard deviations exceeded the mean average of $\mathrm{Cu}$ in NPK-fertilizers and potassium phosphate samples. The high standard deviations found for all the investigated elements even within a single group of fertilizers result on the one hand from the various origins of phosphate rocks, and on the other hand, from the type of processes used in P-fertilizers manufacturing [13]. The residue on the filter during the preparation of the $1 \mathrm{~g} / \mathrm{L}$ solution of fertilizer was examined by XRD. The non-dissolved particles correspond mainly to apatite and quartz in the superphosphate samples. The geological origin of phosphate rocks explains the presence of apatite, quartz, montmorillonite, dolomite, fluorapatite, etc. [48].

The concentrations of phosphate, sulfate, cadmium, lead and the relative abundance of copper and zinc in fertilizer samples are given in Fig. 4. The cadmium distribution in P-fertilizers clearly reaches the highest levels (around $9 \mathrm{mg} / \mathrm{kg}$ ) when the proportion of sulfate increases in the fertilizers. In the absence of sulfate, cadmium remains fluctuant between 1.5 and $2 \mathrm{mg} / \mathrm{kg}$ (Fig. 4a), which is not the case for lead (Fig. 4b). This suggests that cadmium is mainly associated with 
sulfate and in less important amounts with phosphate when sulfate is absent or negligible. However, no direct proportional relationship between cadmium and sulfate can be inferred which actually reflects the various geochemical backgrounds of the fertilizers. The content in lead is between 10 and $15 \mathrm{mg} / \mathrm{kg}$ in fertilizers without revealing a specific affinity for either sulfate or phosphate. The behaviors of copper and zinc are similar to that of lead. The relative abundances of copper and zinc do not show a clear relation with one or another component of the fertilizers, even though the highest relative amounts of copper and zinc were observed in fertilizers of high sulfate contents and the lowest amounts in fertilizers with less or negligible sulfate contents (Fig. 4c).

The results of the Principal Component Analysis (PCA) showed that the eigenvalues of the first three components explain $60.5 \%$ of the total variance correlation (Fig. 5). Cadmium was positively correlated to sulfate (0.516) and calcium (0.705), which is in agreement with what was previously described in Fig. 4. Hence, cadmium is essentially entrapped in the calcium sulfate phases of the fertilizers (Fig. 5). Another positive correlation was found between $\mathrm{Zn}$ and $\mathrm{Pb}$ with $\mathrm{R}=0.590$ (Fig. 5, Table 2). Sb, Ag, Pd, Nb, Mo were strongly correlated to each other ( $\mathrm{R}$ between 0.86 and 0.44 ) and to a lesser extent with $\mathrm{P}_{2} \mathrm{O}_{5}$ (R between 0.48 and 0.24) (Table 2). Such result is consistent with Boyle and Jonasson investigation [49] on the geochemistry of antimony ( $\mathrm{Sb}$ ), which revealed that $\mathrm{Sb}$ can be considered as an indicator of phosphorous and is geochemically associated to $\mathrm{Ag}, \mathrm{P}, \mathrm{Bi}$, $\mathrm{Nb}$ and Mo.

\subsection{Input of trace metals in agricultural soils}

Whatever the guidelines used for describing and characterizing soils, the levels of metals in soils will either fall within the guideline ranges or outside. The metal contents in soils of eastern and southern Mediterranean countries are drastically different (Table 3). For example, in Lebanese soils, the cadmium level is higher than that found in Canadian guidelines unlike the levels of 
copper and lead. Therefore, such data must be discussed separately taking into account the external inputs of metals to the soil, and especially fertilizers inputs that represent the most important source of metals.

The average applications of phosphate fertilizer are $34 \mathrm{~kg} / \mathrm{ha} /$ year in Asia, $133 \mathrm{~kg} / \mathrm{ha} /$ year in India, $600 \mathrm{~kg} / \mathrm{ha} /$ year in Saudi Arabia, which is actually much lower than the $1860 \mathrm{~kg} / \mathrm{ha} / \mathrm{year}$ applied in Lebanon [47, 50, 51]. Knowing the amounts of trace metals in fertilizers and the average amendment per year of P-Fertilizer, the input of trace metals from P-fertilizers into agricultural soils may be estimated.

The P-Fertilizer annual amendment in the eastern Mediterranean countries usually ranges between 20 and $60 \mathrm{~kg}-\mathrm{P} / \mathrm{hectare}$. Such values fluctuate according to agricultural practice, soil $\mathrm{pH}$ and soil humidity. The common practice applies high levels of $\mathrm{P}$-amendment since soil $\mathrm{pH}$ is alkaline under moderate to dry climate. In Table 4, the estimated range of inputs in $\mathrm{Cd}, \mathrm{Pb}, \mathrm{Zn}$ and $\mathrm{Cu}$ are given on P-basis per year. According to the fertilizer used, the supply in cadmium may reach $31 \mathrm{~g} / \mathrm{ha} /$ year when $60 \mathrm{~kg}$ of $\mathrm{P}$ are applied. Lead input varies between 0.95 to $100 \mathrm{~g} / \mathrm{ha} / \mathrm{year}$, zinc between 6.6 to $5257 \mathrm{~g} / \mathrm{ha} /$ year and copper between 0.18 to $26130 \mathrm{~g} / \mathrm{ha} / \mathrm{year}$.

Based on those values, the average input of metals to agricultural soils of eastern Mediterranean countries from phosphate fertilizers may be estimated to $6 \mathrm{~g} \mathrm{Cd} / \mathrm{ha} /$ year, $26 \mathrm{~g} \mathrm{~Pb} / \mathrm{ha} /$ year, $922 \mathrm{~g}$ $\mathrm{Zn} / \mathrm{ha} /$ year and $124 \mathrm{~g} \mathrm{Cu} / \mathrm{ha} /$ year. Such levels are higher than the average values reported for the European countries (e.g. $1.6 \mathrm{~g} \mathrm{Cd} / \mathrm{ha}, 1 \mathrm{~g} \mathrm{~Pb} / \mathrm{ha}$ and $43.1 \mathrm{~g} \mathrm{Zn} / \mathrm{ha}$ ). However, such metal inputs are much lower than the maximum limits set in Brazil and in the United Kingdom [52]. Nevertheless, such estimates and comparisons remain approximations since the metal accumulation in agricultural soil depends not only on the total addition of metal but also on soil $\mathrm{pH}$, humidity and soil compounds. Therefore, in arid regions where soil $\mathrm{pH}$ is mostly alkaline, the metal inputs 
estimated seem to be relatively high even if they remain comparable and lower than the limits established for some countries.

\section{Conclusions}

According to the origin of the phosphate rock and to the fertilizer manufacturing process, the trace metal concentrations may significantly vary within a given type of fertilizer. Cadmium showed the highest concentration in superphosphate, whereas lead, copper and zinc were more abundant in potassium phosphate and NPK-fertilizers. Phosphate minerals were found to be the major trace metal bearing phases for cadmium, molybdenum, antimony, niobium and palladium. Another strong correlation was found between calcium, cadmium and sulfate.

The application of fertilizers is by far the most significant source of trace elements in cropland soils. However, during P-Fertilizer production, metals will precipitate in the less soluble phases, which may mitigate the impact of metal inputs. In Eastern Mediterranean countries, the presence of alkaline soils combined with the arid to semi-arid climate, facilitates the accumulation of trace metals. Therefore, careful attention must be paid when setting the limits for trace metal inputs in soils, which should be based not only on the amount of metals in P-fertilizers but also on the accumulation potential of metals in soils.

\section{Acknowledgements}

We gratefully acknowledge the financial supports provided by the Lebanese National Council for Scientific Research, the Lebanese University and the Lebanese Agriculture Research Institute.

The authors have declared no conflict of interest. 


\section{References}

[1] A.S. Knox, D.I. Kaplan, M.H. Paller, Phosphate sources and their suitability for remediation of contaminated soils, Sci. Total Environ. 2006, 357, 271-279.

[2] L. Giuffré, S. Ratto, L. Marbán, Heavy metals input with phosphate fertilizers used in Argentina, Sci. Total Environ. 1997, 204, 245-250.

[3] M. Rentería-Villalobos, I. Vioque, J. Mantero, G. Manjón, Radiological, chemical and morphological characterizations of phosphate rock and phosphogypsum from phosphoric acid factories in SW Spain, J. Hazard. Mater. 2010, 181, 193-203.

[4] C. Roselli, D. Desideri, M.A. Meli, Radiological characterization of phosphate fertilizers: Comparison between alpha and gamma spectrometry, Microchem. J. 2009, 91, 181-186.

[5] P.M. Rutherford, M.J. Dudas, R.A. Samek, Environmental impacts of phosphogypsum, Sci. Total Environ. 1994, 149, 1-38.

[6] I. Aydin, F. Aydin, A. Saydut, E.G. Bakirdere, C. Hamamci, Hazardous metal geochemistry of sedimentary phosphate rock used for fertilizer (Mazıdag, SE Anatolia, Turkey), Microchem. J. 2010, 96, 247-251.

[7] R. Shahack-Gross, F. Berna, P. Karkanas, S. Weiner, Bat guano and preservation of archaeological remains in cave sites, J. Archaeol. Sci. 2004, 31, 1259-1272.

[8] MM. Makweba, E. Holm, The natural radioactivity of the rock phosphates, phosphatic products and their environmental implications, Sci. Total Environ. 1993, 133, 99-110.

[9] W. Tang, B. Shan, H. Zhang, Phosphorus buildup and release risk associated with agricultural intensification in the estuarine sediments of Chaohu Lake Valley, Eastern China, Clean-Soil, Air, Water, 2010, 38 (4), 336-343. 
[10] W. Jiao, W. Chen, A.C. Chang, A.L. Page, Environmental risks of trace elements associated with long-term phosphate fertilizers applications: a review, Environ. Pollut. 2012, 168, 4453.

[11] R. Lambert, C. Grant, S. Sauvé, Cadmium and zinc in soil solution extracts following the application of phosphate fertilizers, Sci. Total Environ. 2007, 378, 293-305.

[12] G. Nziguheba, E. Smolders, Inputs of trace elements in agricultural soils via phosphate fertilizers in European countries, Sci. Total Environ. 2008, 390, 53-57.

[13] S. Kratz, J. Schick, E. Schnug, Trace elements in rock phosphates and P containing mineral and organo-mineral fertilizers sold in Germany, Sci. Total Environ. 2016, 542, 1013-1019. doi:10.1016/j.scitotenv.2015.08.046.

[14] A.S. Abdel-Haleem, A. Sroor, S.M. El-Bahi, E. Zohny, Heavy metals and rare earth elements in phosphate fertilizer components using instrumental neutron activation analysis, Appl. Radiat. Isot. 2001, 55, 569-573.

[15] A.L. Pérez, K.A. Anderson, DGT estimates cadmium accumulation in wheat and potato from phosphate fertilizer applications, Sci. Total Environ. 2009, 407, 5096-5103.

[16] E. Schnug, B.G. Lottermoser, Fertilizer-derived Uranium and its threat to human health, Environ. Sci. Technol. 2013, 47, 2433-2434.

[17] N. Yamaguchi, A. Kawasaki, I. Iiyama, Distribution of uranium in soil components of agricultural fields after long-term application of phosphate fertilizers, Sci. Total Environ. 2009, 407, 1383-1390.

[18] E. Belon, M. Boisson, I.Z. Deportes, T.K. Eglin, I. Feix, A.O. Bispo, I. Galsomies, S. Leblond, C.R. Guellier, An inventory of trace elements inputs to French agricultural soils, Sci. Total Environ. 2012, 439, 87-95. 
[19] X. Wang, T. Sato, B. Xing, S. Tao, Health risks of heavy metals to the general public in Tianjin, China via consumption of vegetables and fish, Sci. Total Environ. 2005, 350, 2837.

[20] D. Lin, Y. Ouyang, C.H. Huang, D.Y. Huang, Characterization of heavy metals from banana farming soils, CLEAN - Soil, Air, Water 2010, 38 (5-6), 430-436.

[21] A. Takeda, H. Tsukada, Y. Takaku, S. Hisamatsu, M. Nanzyo, Accumulation of uranium derived from long-term fertilizer applications in a cultivated Andisol, Sci. Total Environ. 2006, 367, 924-931.

[22] U. Thawornchaisit, C. Polprasert, Evaluation of phosphate fertilizers for the stabilization of cadmium in highly contaminated soils, J. Hazard. Mater. 2009, 165, 1109-1113.

[23] M. Zhang, J. Pu, Mineral materials as feasible amendments to stabilize heavy metals in polluted urban soils, J. Environ. Sci. 2011, 23 (4), 607-615.

[24] X. Cao, L.Q. Ma, D.R. Rhue, C.S. Appel, Mechanisms of lead, copper, and zinc retention by phosphate rock, Environ. Pollut. 2004, 131, 435-444.

[25] R.X. Cao, L.Q. Ma, M. Chen, S.P. Singh, W.G. Harris, Phosphate-induced metal immobilization in a contaminated site, Environ. Pollut. 2003, 122, 19-28.

[26] X. Cao, A. Wahbi, L. Ma, B. Li, Y. Yang, Immobilization of $\mathrm{Zn}, \mathrm{Cu}$, and $\mathrm{Pb}$ in contaminated soils using phosphate rock and phosphoric acid, J. Hazard. Mater. 2009, 164, $555-564$.

[27] A.A. Abdelhafez, H.H. Abbas, R.S. Abd-El-Aal, N.F. Kandil, J. Li, W. Mahmoud, Environmental and health impacts of successive mineral fertilization in Egypt, Clean- Soil, Air, Water 2012, 40 (4), 356-363. 
[28] O. Dahl, R. Pöykiö, H. Nurmesniemi, Concentrations of heavy metals in fly ash from a coalfired power plant with respect to the Finnish limit value, J. Mater. Cycles Waste Manag. 2008, 10, 87-92.

[29] H. Weigand, M. Bertau, W. Hübner, F. Bohndick, A. Bruckert, RecoPhos : Full-scale fertilizer production from sewage sludge ash, Waste Manag. 2013, 33, 540-544.

[30] B. Hajem, K. Djebali, A. M'nif, Modeling and optimization of fluoride and cadmium trapping in phosphogypsum using design methodology, CLEAN - Soil, Air, Water 2010, 38 (9), 859-864.

[31] P.J. Bridge, Archerite, (K ,NH4)H2P04, a new mineral from Madura, Western Australia, Mineral. Mag. 1977, 41, 33-35.

[32] M.W. Pryce, Biphosphammite: a second occurrence, Mineral. Mag. 1972, 38, 965-967.

[33] M. Singh, M. Garg, Making of anhydrite cement from waste gypsum, Cem. Concr. Res. 2000, 30, 571-577.

[34] G. Jiang, Y. Liu, L. Huang, Q. Fu, Y. Deng, H. Hu, Mechanism of lead immobilization by oxalic acid-activated phosphate rocks, J. Environ. Sci. 2012, 24 (5), 919-925.

[35] M-H. Bernier, G.J. Levy, P. Fine, M. Borisover, Organic matter composition in soils irrigated with treated wastewater: FT-IR spectroscopic analysis of bulk soil samples, Geoderma 2013, 209-210, 233-240.

[36] F.A. Miller, C.H. Wilkins, Infrared Spectra and Characteristic Frequencies of Inorganic Ions., Anal. Chem. 1952, 24(8), 1253-1294.

[37] R.A. Nyquist, R.O. Kagel, Infrared Spectra of Inorganic Compounds (3800-45 cm-1), 1971, $4,1-34$. 
[38] M. Chiban, A. Soudani, F. Sinan, S. Tahrouch, M. Persin, Characterization and application of dried plants to remove heavy metals, nitrate, and phosphate ions from industrial wastewaters, CLEAN - Soil, Air, Water 2011, 39 (4), 376-383.

[39] S. Yalcin, The mechanism of heavy metal biosorption on green marine macroalga Enteromorpha linza, Clean-Soil, Air, Water 2014, 42 (3), 251-259.

[40] Sabiha-Javied, T. Mehmood, M.M. Chaudhry, M. Tufail, N. Irfan, Heavy metal pollution from phosphate rock used for the production of fertilizer in Pakistan, Microchem. J. 2009, 91, 94-99.

[41] E. Gimeno-Garcia, V. Andreu, R. Boluda, Heavy metals incidence in the application of inorganic fertilizers and pesticides to rice farming soils, Environ. Pollut. 1996, 92 (1), 1925.

[42] D. Uprety, M. Hejcman, J. Szakova, E. Kunzova, P. Tlustos, Concentration of trace elements in arable soil after long-term application of organic and inorganic fertilizers, Nutr. Cycl. Agroecosystems 2009, 85, 241-252.

[43] B.R. Singh, K. Myhr, Cadmium uptake by barley as affected by Cd sources and pH levels., Geoderma 1998, 84, 185-194.

[44] M.F. Akhter, C.R. Omelon, R.A. Gordon, D. Moser, S.M. Macfie, Localization and chemical speciation of cadmium in the roots of barley and lettuce, Environ. Exp. Bot. 2014, $100,10-19$.

[45] S. Sauvé, M. McBride, W. Hendershot, Lead Phosphate Solubility in Water and Soil Suspensions, Environ. Sci. Technol. 1998, 32 (3), 388-393.

[46] N. Köleli, S. Eker, I. Cakmak, Effect of zinc fertilization on cadmium toxicity in durum and bread wheat grown in zinc-deficient soil, Environ. Pollut. 2004, 131, 453-459. 
[47] D.K. Gupta, S. Chatterjee, S. Datta, V. Veer, C. Walther, Role of phosphate fertilizers in heavy metal uptake and detoxification of toxic metals, Chemosphere 2014, 108, 134-144.

[48] P.M. Rutherford, M.J. Dudas, R.A. Samek, Environmental impacts of phosphogypsum, Sci. Total Environ. 1994, 149, 1-38.

[49] R.W. Boyle, I.R. Jonasson, The geochemistry of antimony and its use as an indicatore element in geochemical prospecting, J. Geochemical Explor. 1984, 20, 223-302.

[50] FAO, "Fertilizer use by crop," in FAO Fertilizer and Plant Nutrition Bulletin, Rome, Italy, 2006.

[51] N. Farajalla, M. Marktanner, L. Dagher, P. Zgheib, The National Economic, Environment and Development Studies (NEEDS) for Climate Change Project -Final Report, Issam Fares Institute for Public Policy and International Affairs - American University of Beirut, Beirut. 2010.

[52] F.T. Conceição, D.M. Bonotto, Radionuclides, heavy metals and fluorine incidence at Tapira phosphate rocks, Brazil, and their industrial (by) products, Environ. Pollut. 2006, $139,232-243$.

[53] J. Aslam, S.A. Khan, S.H. Khan, Heavy metals contamination in roadside soil near different traffic signals in Dubai, Unites Arab Emirates, J. Saudi Chem. Soc. 2013, 17, 315-319.

[54] H.J. Kanbar, N. Hanna, A.G. El-Samrani, A. Kobaissi, N. Harb, N. Amacha, Metal binding in soil cores and sediments in the vicinity of a dammed agricultural and industrial watershed, Environ. Monit. Assess. 2014, 186 (12), 8793-8806.

[55] Y. Al Naggar, E. Naiem, M. Mona, J. Giesy, A. Seif, Metals in agricultural soils and plants in Egypt, Toxicol. Environ. Chem. 2014, 96 (5), 730-742. 
[56] R.H. Habib, S.M. Awadh, M. Muslim, Toxic heavy metals in soil and some plants in Beghdad, Iraq, J. Al-Nahrain University 2012, 15 (2), 1-16.

[57] A. Esmaeili, F. Moore, B. Keshavarzi, N. Jaafarzadeh, M. Kermani, M, A geochemical survey of heavy metals in agricultural and background soils of the Isfahan industrial zone, Iran, Catena 2014, 121, 88-98.

[58] A. Möller, H.W. Müller, A. Abdullah, G. Abdelgawad, J. Utermann, Urban soil pollution in Damascus, Syria: concentrations and patterns of heavy metals in the soils of the Damascus Ghouta, Geoderma 2005, 124, 63-71.

[59] G. Daldoul, R. Souissi, F. Souissi, N. Jemmali, H.K. Chakroun, Assessment and mobility of heavy metals in carbonated soils contaminated by old mine tailings in North Tunisia, J. Afr. Earth Sci. 2015, 110, 150-159.

[60] Z. Fatna, C. Zakaria, M. Fatimaezzahra, M. Kawtar, N. Saber, Assessment of environmental quality in soil under wheat and vines in Bouznika-Benslimane region of Morocco. Eur. Sci. J. 2014, 20 (24), 23-33.

[61] S. Maas, R. Scheifler, M. Benslama, N. Crini, E. Lucot, Z. Brahmia, S. Benyacoub, P. Giraudoux, Spatial distribution of heavy metal concentrations in urban, suburban and agricultural soils in a Mediterranean city of Algeria, Environ. Pollut. 2010, 158, 2294-2301. 


\section{Supporting Information}

Figure S1 Typical diffractograms of Potassium Phosphate (K.P; sample 38), Urea-Phosphate (U.P; sample 43), Superphosphate (S.P; sample 13) and NPK (sample 4). The black arrows correspond to the 2-theta value of 23.952 on the K.P, 9.971 on the U.P, 18.211, 23.057 and 31.495 on the S.P and 16.681 and 22.32 on the N.P.K.

Figure S2 Typical infrared spectra of Superphosphate (S.P; sample 13), Urea-phosphate (U.P; sample 40), NPK fertilizers (sample 7) and Potassium Phosphate (K.P; sample 38) 


\section{Figure captions}

Figure 1. Frequency distribution of the Intensity ratio of the typical functional groups $\left(\mathrm{I}_{\mathrm{P}-\mathrm{O}} / \mathrm{I}_{\mathrm{S}-\mathrm{O}}, \mathrm{I}_{\mathrm{P}-}\right.$ $\mathrm{O} / \mathrm{I}_{\mathrm{N}-\mathrm{H}}$ and $\left.\mathrm{I}_{\mathrm{P}-\mathrm{O}} / \mathrm{I}_{\mathrm{N}-\mathrm{O}}\right)$

Figure 2. Frequency distribution of cadmium in P- fertilizer samples (mg Cd/kg-P)

Figure 3. Frequency distribution in P-fertilizer samples of a) Lead, b) Zinc and c) Copper in $(\mathrm{mg} / \mathrm{kg})$

Figure 4. a) P, S, and $\mathrm{Cd}$, b) $\mathrm{P}, \mathrm{S}$ and $\mathrm{Pb}, \mathrm{c}) \mathrm{P}, \mathrm{S}, \mathrm{Zn}(\%)$ and $\mathrm{Cu}(\%)$ in fertilizer samples

Figure 5. Pearson correlation of all compounds in NPK fertilizer 
Table 1. List of fertilizers used in this study and their characteristics

\begin{tabular}{|c|c|c|c|c|c|c|c|c|c|c|c|c|}
\hline $\begin{array}{c}\text { Formula (N-P-K) } \\
\% \text { wt }\end{array}$ & Origin $^{a}$ & $\mathbf{p H}$ & EC & $\mathbf{P}_{2} \mathbf{O}_{5}$ & $\mathrm{SO}_{3}$ & $\mathbf{K}_{2} \mathbf{O}$ & Cd & $\mathbf{P b}$ & Zn & $\mathrm{Cu}$ & $\mathbf{F e}$ & $\mathbf{C a}$ \\
\hline & & & $\mathrm{mS} / \mathrm{cm}$ & \multicolumn{3}{|c|}{$(\%)$} & \multicolumn{4}{|c|}{$(\mathrm{mg} / \mathrm{kg})$} & \multicolumn{2}{|c|}{$(\mathrm{g} / \mathrm{kg})$} \\
\hline $12-7-17+2 \mathrm{MgO}$ & $\mathrm{BE}$ & $6.68 \pm 0.02$ & $1.535 \pm 0.005$ & $5.8 \pm 0.2$ & $18.9 \pm 0.1$ & $18.2 \pm 0.8$ & $4.81 \pm 0.08$ & $20.8 \pm 0.1$ & $105 \pm 1$ & $7.5 \pm 0.1$ & $1.56 \pm 0.04$ & $29.2 \pm 0.4$ \\
\hline $11-12-17$ & IT & $6.62 \pm 0.01$ & $1.258 \pm 0.003$ & $7.33 \pm 0.02$ & $21.7 \pm 0.1$ & $17.5 \pm 0.8$ & $6.17 \pm 0.22$ & $13.82 \pm 0.03$ & $114 \pm 2$ & $118 \pm 1$ & $0.86 \pm 0.01$ & $33.5 \pm 0.7$ \\
\hline $16-8-12+2$ & $\mathrm{DE}$ & $5.89 \pm 0.01$ & $1.472 \pm 0.004$ & $5.7 \pm 0.1$ & $4.2 \pm 0.2$ & $13.4 \pm 0.8$ & $2.58 \pm 0.17$ & $8.33 \pm 0.05$ & $144 \pm 1$ & $263.2 \pm 2.5$ & $4.29 \pm 0.01$ & $6.76 \pm 0.04$ \\
\hline $20-20-20$ & IT & $5.06 \pm 0.01$ & $0.923 \pm 0.001$ & $20.6 \pm 0.2$ & $9.42 \pm 0.01$ & $21.3 \pm 0.8$ & $1.92 \pm 0.05$ & $11.1 \pm 0.8$ & $99 \pm 1$ & $77.5 \pm 0.6$ & $0.39 \pm 0.01$ & $1.29 \pm 0.04$ \\
\hline $20-20-20+\mathrm{TE}^{\mathrm{b}}$ & $\mathrm{JO}$ & $5.11 \pm 0.02$ & $1.102 \pm 0.001$ & $20.3 \pm 0.8$ & $0^{*}$ & $20.2 \pm 0.8$ & $1.76 \pm 0.03$ & $6.91 \pm 0.01$ & $240.3 \pm 0.5$ & $1.75 \pm 0.05$ & $0.041 \pm 0.001$ & $0.98 \pm 0.01$ \\
\hline $30-10-10+\mathrm{TE}$ & JO & $5.24 \pm 0.03$ & $0.727 \pm 0.003$ & $9.6 \pm 0.3$ & $10.11 \pm 0.02$ & $10.7 \pm 1.7$ & $1.12 \pm 0.04$ & $6.9 \pm 0.2$ & $101.4 \pm 0.2$ & $53.4 \pm 0.4$ & $0.35 \pm 0.01$ & $1.4 \pm 0.4$ \\
\hline $20-5-8+2$ & DE & $6.94 \pm 0.03$ & $1.018 \pm 0.002$ & $3.8 \pm 0.2$ & $23 \pm 1$ & $8.36 \pm 0.04$ & $1.95 \pm 0.03$ & $9.28 \pm 0.07$ & $29.7 \pm 0.2$ & $24.1 \pm 2.2$ & $3.6 \pm 0.1$ & $8.54 \pm 0.03$ \\
\hline 12-12-17+2+TE & $\mathrm{DE}$ & $6.01 \pm 0.02$ & $1.673 \pm 0.001$ & $5.9 \pm 0.3$ & $34.3 \pm 0.4$ & $18.3 \pm 1.3$ & $3.35 \pm 0.08$ & $11.3 \pm 0.1$ & $30.6 \pm 0.7$ & $10.01 \pm 0.07$ & $3.75 \pm 0.05$ & $10.13 \pm 0.02$ \\
\hline $17-17-17$ & RU & $5.89 \pm 0.04$ & $1.438 \pm 0.003$ & $15.1 \pm 1.3$ & $0 *$ & $18.2 \pm 0.8$ & $2.03 \pm 0.02$ & $12.3 \pm 0.6$ & $128 \pm 1$ & $13.6 \pm 0.3$ & $2.3 \pm 0.1$ & $11.76 \pm 0.04$ \\
\hline $16-16-16$ & RU & $6.11 \pm 0.05$ & $1.448 \pm 0.001$ & $16.5 \pm 0.1$ & $0 *$ & $16.2 \pm 0.2$ & $1.83 \pm 0.25$ & $11.4 \pm 0.2$ & $153 \pm 1$ & $14.8 \pm 0.1$ & $1.82 \pm 0.01$ & $11.14 \pm 0.01$ \\
\hline $15-15-15$ & NO & $5.77 \pm 0.06$ & $1.492 \pm 0.001$ & $15.7 \pm 0.1$ & $6.03 \pm 0.05$ & $16.2 \pm 0.4$ & $6.76 \pm 0.06$ & $12.8 \pm 0.7$ & $98.6 \pm 2.6$ & $14 \pm 1$ & $1.89 \pm 0.04$ & $13.61 \pm 0.04$ \\
\hline $\begin{array}{l}12-12-17+2 \mathrm{MgO} \\
+22 \mathrm{SO}_{3}\end{array}$ & IT & $7.33 \pm 0.02$ & $1.021 \pm 0.002$ & $4.245 \pm 0.003$ & $21.8 \pm 0.2$ & $17.6 \pm 0.8$ & $9.03 \pm 0.05$ & $13.1 \pm 0.1$ & $35.8 \pm 0.5$ & $4.4 \pm 0.1$ & $3.73 \pm 0.01$ & $34.7 \pm 0.1$ \\
\hline $18-20 \% \mathrm{P}_{2} \mathrm{O}_{5}$ & LB & $3.61 \pm 0.01$ & $1.022 \pm 0.004$ & $18.5 \pm 0.1$ & $34 \pm 5$ & $0^{*}$ & $5.69 \pm 0.05$ & $9.23 \pm 0.11$ & $92.3 \pm 0.5$ & $7.81 \pm 0.01$ & $0.84 \pm 0.01$ & $59.7 \pm 1.5$ \\
\hline $15-15-15+10 \mathrm{SO}_{3}$ & IT & $3.72 \pm 0.01$ & $1.044 \pm 0.001$ & $5.8 \pm 0.2$ & $13.76 \pm 0.05$ & $15.05 \pm 0.17$ & $7.61 \pm 0.05$ & $13.01 \pm 0.13$ & $37.6 \pm 0.7$ & $16.81 \pm 0.03$ & $4.71 \pm 0.05$ & $39.9 \pm 0.3$ \\
\hline $12-12-17+2+20$ & IT & $3.31 \pm 0.03$ & $1.633 \pm 0.002$ & $7.8 \pm 0.2$ & $19 \pm 1$ & $16.9 \pm 0.4$ & $6.85 \pm 0.07$ & $12.72 \pm 0.15$ & $68.5 \pm 0.1$ & $13.1 \pm 0.1$ & $1.74 \pm 0.05$ & $14.5 \pm 0.5$ \\
\hline $0-42-28$ & ES & $4.41 \pm 0.04$ & $5.549 \pm 0.001$ & $39.6 \pm 1.1$ & $0 *$ & $28.3 \pm 0.1$ & $1.77 \pm 0.04$ & $8.75 \pm 0.17$ & $294.1 \pm 0.2$ & $59 \pm 5$ & $0.018 \pm 0.001$ & $0.75 \pm 0.01$ \\
\hline $20-20-20$ & $\mathrm{BE}$ & $5.35 \pm 0.01$ & $0.951 \pm 0.001$ & $20.5 \pm 0.6$ & $1.12 \pm 0.01$ & $20.3 \pm 0.4$ & $1.71 \pm 0.03$ & $12.11 \pm 0.05$ & $28.7 \pm 0.2$ & $20.6 \pm 2.9$ & $0.0759 \pm 0.0001$ & $0.4 \pm 0.2$ \\
\hline 28-14-14+TE & TR & $5.11 \pm 0.01$ & $0.678 \pm 0.003$ & $14.8 \pm 0.4$ & $0.62 \pm 0.02$ & $14.9 \pm 0.8$ & $1.19 \pm 0.03$ & $10.1 \pm 0.4$ & $423 \pm 1$ & $49.2 \pm 0.5$ & $0.58 \pm 0.01$ & $0.75 \pm 0.06$ \\
\hline $13-40-13+\mathrm{TE}$ & TR & $4.79 \pm 0.06$ & $0.962 \pm 0.003$ & $41.3 \pm 0.7$ & $0.577 \pm 0.002$ & $13.9 \pm 0.8$ & $2.04 \pm 0.05$ & $11.7 \pm 0.1$ & $248.9 \pm 0.2$ & $44.6 \pm 0.1$ & $0.481 \pm 0.003$ & $0.7 \pm 0.1$ \\
\hline 20-20-20+TE & TR & $5.18 \pm 0.02$ & $0.888 \pm 0.003$ & $20.4 \pm 0.9$ & $0.7289 \pm 0.0004$ & $19.5 \pm 0.4$ & $1.70 \pm 0.01$ & $10.3 \pm 0.1$ & $400 \pm 1$ & $65.9 \pm 0.2$ & $0.66 \pm 0.01$ & $0.7379 \pm 0.0003$ \\
\hline $11-9-36+\mathrm{TE}$ & TR & $3.58 \pm 0.04$ & $1.337 \pm 0.002$ & $12.91 \pm 0.05$ & $18.1 \pm 0.1$ & $36.4 \pm 0.8$ & $2.79 \pm 0.06$ & $13.79 \pm 0.14$ & $453 \pm 1$ & $59.9 \pm 0.1$ & $0.64 \pm 0.01$ & $0.8 \pm 0.1$ \\
\hline $8-8.5-6$ & IT & $8.05 \pm 0.07$ & $3.092 \pm 0.003$ & $8.94 \pm 0.04$ & $0 *$ & $6.8 \pm 1.3$ & $0.74 \pm 0.01$ & $5.07 \pm 0.01$ & $94.3 \pm 0.5$ & $68.6 \pm 0.3$ & $0.096 \pm 0.001$ & $0.85 \pm 0.01$ \\
\hline $7-6-7$ & FR & $6.54 \pm 0.03$ & $0.708 \pm 0.003$ & $6.7 \pm 0.4$ & $19.9 \pm 0.1$ & $6.9 \pm 0.4$ & $2.46 \pm 0.04$ & $10.77 \pm 0.02$ & $377 \pm 1$ & $84.2 \pm 1.8$ & $5.12 \pm 0.03$ & $37.5 \pm 0.4$ \\
\hline $\begin{array}{l}20-5-10+2 \mathrm{MgO} \\
+1 \mathrm{Fe}\end{array}$ & IT & $6.79 \pm 0.01$ & $0.409 \pm 0.003$ & $4.8 \pm 0.1$ & $11.6 \pm 0.1$ & $7.5 \pm 0.4$ & $4.26 \pm 0.03$ & $8.08 \pm 0.16$ & $133.1 \pm 0.3$ & $6.06 \pm 0.03$ & $19.1 \pm 0.1$ & $32.7 \pm 0.2$ \\
\hline $46-48 \% \mathrm{P}_{2} \mathrm{O}_{5}$ & LB & $3.71 \pm 0.01$ & $0.633 \pm 0.002$ & $48.1 \pm 0.2$ & $3.4 \pm 0.1$ & $0^{*}$ & $9.43 \pm 0.02$ & $14.47 \pm 0.06$ & $386 \pm 3$ & $8.7 \pm 0.2$ & $1.991 \pm 0.005$ & $239 \pm 1$ \\
\hline $28-14-14+\mathrm{TE}$ & FR & $4.81 \pm 0.01$ & $0.639 \pm 0.001$ & $14.4 \pm 0.3$ & $0^{*}$ & $14.9 \pm 0.3$ & $0.91 \pm 0.03$ & $9.05 \pm 0.08$ & $204 \pm 4$ & $1.8 \pm 0.1$ & $0.13 \pm 0.02$ & $0.97 \pm 0.01$ \\
\hline $20-20-20$ & IT & $5.03 \pm 0.05$ & $0.864 \pm 0.001$ & $19.7 \pm 0.2$ & $0^{*}$ & $19.12 \pm 0.04$ & $2.11 \pm 0.03$ & $13.7 \pm 0.2$ & $1144 \pm 1$ & $30.9 \pm 3.8$ & $0.34 \pm 0.01$ & $0.87 \pm 0.01$ \\
\hline $20-20-20$ & US & $6.71 \pm 0.03$ & $1.119 \pm 0.001$ & $20.7 \pm 0.2$ & $0^{*}$ & $21 \pm 1$ & $1.91 \pm 0.03$ & $12.43 \pm 0.08$ & $310 \pm 1$ & $507 \pm 2$ & $1.13 \pm 0.02$ & $0.978 \pm 0.003$ \\
\hline $30-10-10$ & US & $5.42 \pm 0.01$ & $0.662 \pm 0.001$ & $10.8 \pm 0.2$ & $6.81 \pm 0.02$ & $10.43 \pm 0.01$ & $1.27 \pm 0.07$ & $4.89 \pm 0.01$ & $366 \pm 1$ & $421 \pm 4$ & $1.15 \pm 0.01$ & $0.48 \pm 0.01$ \\
\hline $4-2-41$ & IT & $4.21 \pm 0.02$ & $1.312 \pm 0.003$ & $2.87 \pm 0.07$ & $28.3 \pm 0.1$ & $44.9 \pm 0.3$ & $1.99 \pm 0.04$ & $14.22 \pm 0.05$ & $356 \pm 3$ & $380 \pm 4$ & $1.29 \pm 0.02$ & $1.85 \pm 0.01$ \\
\hline $12-48-8$ & US & $5.42 \pm 0.03$ & $0.974 \pm 0.001$ & $47.5 \pm 0.3$ & $2.48 \pm 0.05$ & $8.2 \pm 0.1$ & $2.08 \pm 0.05$ & $27.3 \pm 0.3$ & $346 \pm 2$ & $35.4 \pm 1.1$ & $0.91 \pm 0.01$ & $0.4 \pm 0.1$ \\
\hline $15-15-15+15 \mathrm{SO}_{3}$ & $\mathrm{BE}$ & $6.63 \pm 0.01$ & $1.163 \pm 0.001$ & $15.2 \pm 0.2$ & $28.58 \pm 0.04$ & $18.6 \pm 0.4$ & $3.88 \pm 0.14$ & $58.5 \pm 2.5$ & $5575 \pm 3$ & $90.9 \pm 0.2$ & $1.69 \pm 0.02$ & $1.3 \pm 0.7$ \\
\hline 20-20-20+TE & SA & $4.59 \pm 0.01$ & $0.774 \pm 0.001$ & $20.53 \pm 0.03$ & $5.51 \pm 0.01$ & $18.9 \pm 0.1$ & $2.61 \pm 0.01$ & $26.3 \pm 0.1$ & $50.5 \pm 3.9$ & $37.9 \pm 0.5$ & $0.088 \pm 0.002$ & $1.21 \pm 0.02$ \\
\hline
\end{tabular}




\begin{tabular}{|c|c|c|c|c|c|c|c|c|c|c|c|c|}
\hline $15-15-15$ & UA & $6.82 \pm 0.03$ & $1.553 \pm 0.002$ & $15.1 \pm 0.1$ & $24.12 \pm 0.02$ & $14.6 \pm 0.1$ & $5.08 \pm 0.02$ & $12.14 \pm 0.01$ & $93 \pm 2$ & $1.5 \pm 0.9$ & $3.65 \pm 0.03$ & $1.04 \pm 0.03$ \\
\hline $25-10-17$ & $\mathrm{DE}$ & $5.49 \pm 0.01$ & $0.861 \pm 0.001$ & $10.479 \pm 0.003$ & $3.5 \pm 0.3$ & $16.98 \pm 0.01$ & $0.62 \pm 0.06$ & $7.55 \pm 0.06$ & $171 \pm 2$ & $77.13 \pm 0.02$ & $0.37 \pm 0.01$ & $0.46 \pm 0.05$ \\
\hline 20-20-20+TE & & $4.91 \pm 0.02$ & $0.832 \pm 0.003$ & $18.6 \pm 0.1$ & $3.4 \pm 0.1$ & $20.1 \pm 0.1$ & $2.03 \pm 0.01$ & $15.87 \pm 0.02$ & $415 \pm 7$ & $35.6 \pm 0.1$ & $0.22 \pm 0.01$ & $0.5 \pm 0.2$ \\
\hline $20-20-20$ & $\mathrm{NO}$ & $5.62 \pm 0.03$ & $1.291 \pm 0.002$ & $20.4 \pm 0.2$ & $10.43 \pm 0.05$ & $19.9 \pm 0.3$ & $3.42 \pm 0.04$ & $19.12 \pm 0.43$ & $134.4 \pm 0.1$ & $11.83 \pm 0.05$ & $1.33 \pm 0.04$ & $13.7 \pm 0.2$ \\
\hline $0-52-34$ & $\mathrm{BE}$ & $4.62 \pm 0.02$ & $0.793 \pm 0.001$ & $53.1 \pm 0.4$ & $0 *$ & $32.5 \pm 0.2$ & $3.41 \pm 0.02$ & $24.3 \pm 0.2$ & $204.2 \pm 0.4$ & $2.11 \pm 0.03$ & $0.034 \pm 0.001$ & $0.87 \pm 0.01$ \\
\hline $\begin{array}{l}1-12-17+2 \mathrm{MgO} \\
+20 \mathrm{SO}_{3} \\
\end{array}$ & NL & $6.51 \pm 0.02$ & $1.369 \pm 0.001$ & $9.4 \pm 0.2$ & $22.81 \pm 0.04$ & $17.2 \pm 0.4$ & $2.29 \pm 0.02$ & $16.13 \pm 0.03$ & $368.6 \pm 0.5$ & $18.6 \pm 0.1$ & $1.81 \pm 0.03$ & $12.6 \pm 0.2$ \\
\hline $17.5-44-0$ & $\mathrm{BE}$ & $2.31 \pm 0.01$ & $1.647 \pm 0.002$ & $44.1 \pm 0.1$ & $0 *$ & $0 *$ & $1.75 \pm 0.04$ & $11.2 \pm 0.8$ & $140.4 \pm 0.3$ & $2.03 \pm 0.02$ & $0.361 \pm 0.003$ & $0.45 \pm 0.01$ \\
\hline $20-20-20$ & IT & $5.46 \pm 0.01$ & $1.251 \pm 0.001$ & $20.61 \pm 0.01$ & $2.77 \pm 0.03$ & $20.07 \pm 0.05$ & $0.99 \pm 0.12$ & $11.94 \pm 0.16$ & $1237 \pm 0.2$ & $49 \pm 2$ & $0.055 \pm 0.002$ & $0.41 \pm 0.01$ \\
\hline $\begin{array}{l}15-15-15+2 \mathrm{MgO}+ \\
15 \mathrm{SO}_{3}+5 \mathrm{CaO}+1 \mathrm{Zn}\end{array}$ & $\mathrm{BE}$ & $7.19 \pm 0.01$ & $1.521 \pm 0.005$ & $8.1 \pm 0.1$ & $16.33 \pm 0.04$ & $14.7 \pm 0.4$ & $5.70 \pm 0.07$ & $25.4 \pm 1.2$ & $5735 \pm 4$ & $22.3 \pm 0.1$ & $1.59 \pm 0.01$ & $11.01 \pm 0.03$ \\
\hline $17-44-0$ & $\mathrm{JO}$ & $2.21 \pm 0.02$ & $1.913 \pm 0.002$ & $43.1 \pm 0.1$ & $2.84 \pm 0.02$ & $0 *$ & $2.94 \pm 0.02$ & $12.6 \pm 0.2$ & $142 \pm 3$ & $5.07 \pm 0.06$ & $1.29 \pm 0.03$ & $0.3 \pm 0.1$ \\
\hline $20-20-20+\mathrm{TE}$ & $\mathrm{BE}$ & $5.32 \pm 0.01$ & $1.266 \pm 0.001$ & $20.82 \pm 0.04$ & $3.019 \pm 0.004$ & $18.88 \pm 0.05$ & $2.46 \pm 0.02$ & $14.2 \pm 0.1$ & $515 \pm 1$ & $91.6 \pm 0.1$ & $0.65 \pm 0.01$ & $1.1 \pm 0.1$ \\
\hline
\end{tabular}

${ }^{a}$ Abbreviation of the country of origin according to the ISO (International Organization for Standardization); BE: Belgium, FR: France, DE: Germany, IT: Italy, JO: Jordan, LB: Lebanon, NL: Netherlands, NO: Norway, RU: Russian Federation, SA: Saudi Arabia; ES: Spain, TR: Turkey, UA: Ukraine, US: Unites States ${ }^{\mathrm{b}}$ TE: Trace Element

*Below the detection limit 
Table 2. Pearson correlation of all compounds in NPK fertilizers

\begin{tabular}{|c|c|c|c|c|c|c|c|c|c|c|c|c|c|c|c|c|}
\hline & $\mathrm{Sb}$ & Pd & Ag & Mo & $\mathrm{Nb}$ & $\mathrm{Zr}$ & $\mathbf{B i}$ & Zn & $\mathrm{Cu}$ & $\mathbf{F e}$ & Mn & $\mathbf{P b}$ & Cd & $\mathrm{Ca}$ & $\mathbf{P}_{2} \mathbf{O}_{5}$ & $\mathrm{SO}_{4}$ \\
\hline Sb & 1 & & & & & & & & & & & & & & & \\
\hline Pd & 0.474 & 1 & & & & & & & & & & & & & & \\
\hline Ag & 0.499 & 0.528 & 1 & & & & & & & & & & & & & \\
\hline Mo & 0.438 & 0.605 & 0.856 & 1 & & & & & & & & & & & & \\
\hline $\mathrm{Nb}$ & 0.580 & $\mathbf{0 . 7 3 0}$ & 0.739 & 0.808 & 1 & & & & & & & & & & & \\
\hline $\mathrm{Zr}$ & -0.190 & -0.187 & -0.045 & -0.050 & -0.179 & 1 & & & & & & & & & & \\
\hline Bi & 0.070 & -0.320 & -0.194 & -0.221 & -0.364 & 0.383 & 1 & & & & & & & & & \\
\hline $\mathbf{Z n}$ & -0.288 & -0.191 & -0.145 & -0.160 & -0.100 & -0.202 & -0.205 & 1 & & & & & & & & \\
\hline $\mathrm{Cu}$ & -0.010 & 0.215 & 0.119 & 0.335 & 0.205 & -0.119 & -0.116 & -0.046 & 1 & & & & & & & \\
\hline $\mathrm{Fe}$ & -0.413 & -0.171 & -0.325 & -0.249 & -0.305 & 0.156 & -0.044 & -0.340 & -0.092 & 1 & & & & & & \\
\hline Mn & 0.005 & 0.161 & 0.062 & 0.094 & 0.251 & 0.044 & -0.135 & 0.350 & 0.149 & -0.252 & 1 & & & & & \\
\hline $\mathrm{Pb}$ & -0.206 & -0.273 & -0.071 & -0.150 & -0.261 & -0.022 & -0.103 & 0.590 & -0.098 & -0.229 & -0.173 & 1 & & & & \\
\hline Cd & -0.208 & -0.480 & -0.397 & -0.434 & -0.586 & -0.128 & 0.173 & -0.030 & -0.245 & 0.360 & -0.495 & 0.198 & 1 & & & \\
\hline Ca & -0.316 & -0.444 & -0.367 & -0.396 & -0.557 & 0.051 & 0.201 & -0.150 & -0.215 & 0.591 & -0.400 & 0.071 & 0.705 & 1 & & \\
\hline $\mathbf{P}_{2} \mathbf{O}_{5}$ & 0.291 & 0.242 & $\mathbf{0 . 2 4 3}$ & $\mathbf{0 . 3 2 9}$ & 0.476 & -0.069 & -0.113 & $\mathbf{0 . 1 9 1}$ & 0.138 & -0.477 & 0.576 & 0.083 & -0.459 & -0.630 & 1 & \\
\hline $\mathrm{SO}_{4}$ & -0.256 & -0.341 & -0.335 & -0.358 & -0.534 & -0.260 & -0.008 & 0.017 & 0.038 & 0.367 & -0.502 & 0.241 & 0.516 & 0.502 & -0.602 & 1 \\
\hline
\end{tabular}


Table 3. Trace metals in soil from eastern and southern Mediterranean countries

\begin{tabular}{lcccccc}
\hline & $\mathrm{Cd}$ & $\mathrm{Zn}$ & $\mathrm{Pb}$ & $\mathrm{Cu}$ & $\mathrm{Cr}$ & \\
\hline Dubai & $0.17-1.01$ & $3.34-170.27$ & $6.92-2784$ & $0.82-65.9$ & & {$[53]$} \\
\hline Lebanon & $0.28-2.8$ & \multicolumn{7}{c}{$11.3-22.9$} & $25.3-54.2$ & & {$[54]$} \\
\hline Egypt & $12-16$ & $36-41$ & $46-79$ & $28-29$ & & {$[55]$} \\
\hline Iraq & $11-41$ & \multicolumn{7}{c}{$29-183$} & & & {$[56]$} \\
\hline Iran & $0.11-8.68$ & $50.2-1510.3$ & $7.2-319.3$ & $15.4-84$ & $67-116$ & {$[57]$} \\
\hline Syria & $46-293$ & $<5-108$ & $16-97$ & $12-116$ & {$[58]$} \\
\hline Tunisia & 16.5 & 3337.6 & 676 & & & {$[59]$} \\
\hline Morocco & $0.52-0.81$ & $261.98-791.63$ & $38.36-67.14$ & 66.7 & & {$[60]$} \\
\hline Algeria & $0.01-14.15$ & $4.7-258.8$ & $3.1-823.7$ & $0.2-132.1$ & $7.4-111.5$ & {$[61]$} \\
\hline
\end{tabular}


Table 4. Estimated range of inputs in $\mathrm{Cu}, \mathrm{Pb}, \mathrm{Zn}$ and $\mathrm{Cd}$ (g/ha/year) in agricultural soil

\begin{tabular}{|l|c|c|c|c|}
\hline \multicolumn{5}{|c|}{ Minimum application of 20 kg P/ha/year } \\
\hline & Input of $\mathrm{Cu}$ & Input of $\mathrm{Pb}$ & Input of $\mathrm{Zn}$ & Input of $\mathrm{Cd}$ \\
\hline \multicolumn{5}{|c|}{$(\mathrm{g} / \mathrm{ha} /$ year) } \\
\hline Min/max & $0.185 / 871$ & $0.95 / 32.59$ & $6.6 / 1752.4$ & $0.183 / 10.34$ \\
\hline \multicolumn{5}{|c|}{ Maximum application of 60 kg P/ha/year } \\
\hline & Input of $\mathrm{Cu}$ & Input of $\mathrm{Pb}$ & Input of $\mathrm{Zn}$ & Input of Cd \\
\hline \multicolumn{5}{|c|}{ (g/ha/year) } \\
\hline Min/max & $0.56 / 26130$ & $2.84 / 98$ & $19.8 / 5257.2$ & $0.54 / 31$ \\
\hline
\end{tabular}

